\title{
mRNA-Expression of ER $\alpha$, ER $\beta$, and PR in Clonal Stem Cell Cultures Obtained from Human Endometrial Biopsies
}

\author{
A. N. Schüring, J. Braun, S. Wüllner, L. Kiesel, and M. Götte \\ Department of Gynecology and Obstetrics, University of Münster, Medical Center, 48149 Münster, Germany
}

Received 9 August 2011; Accepted 5 September 2011

Academic Editor: George Yip

Background. Proliferation and differentiation of the endometrium are regulated by estrogen and progesterone. The enormous regenerative capacity of the endometrium is thought to be based on the activity of adult stem cells. However, information on endocrine regulatory mechanisms in human endometrial stem cells is scarce. In the present study, we investigated the expression of $\mathrm{ER} \alpha, \mathrm{ER} \beta$, and $\mathrm{PR}$ in clonal cultures of human endometrial stem cells derived from transcervical biopsies. Methods. Endometrial tissue of 11 patients was obtained by transcervical biopsy. Stromal cell suspensions were plated at clonal density and incubated for 15 days. Expression of $\mathrm{ER} \alpha, \mathrm{ER} \beta$ and PR was determined by qPCR prior to and after one cloning round, and normalized to $18 \mathrm{~S}$ rRNA expression. Results. Expression of $\mathrm{ER} \alpha$ and $\mathrm{ER} \beta$ was downregulated by $64 \%$ and $89 \%$, respectively $(P=0.002$ and $P<0.001)$. In contrast, PR was not significantly downregulated, due to a more heterogenous expression pattern. Conclusions. Culture of human endometrial stroma cells results in a downregulation of $\mathrm{ER} \alpha$ and $\mathrm{ER} \beta$, while expression of $\mathrm{PR}$ remained unchanged in our patient collective. These results support the hypothesis that stem cells may not be subject to direct stimulation by sex steroids, but rather by paracrine mechanisms within the stem cell niche.

KEYWORDS: stem cells, endometrium, estrogen receptor, progesterone receptor, and endometriosis. 


\section{INTRODUCTION}

\subsection{Stem Cells in the Endometrium}

Stem cells have been long thought to participate in the physiological function of the endometrium providing the basis for monthly remodeling during the reproductive phase of women [1]. This view is not only supported by findings of a clonal origin of endometrial glands and cultured endometrial cells [2-4], but also by the demonstration of stem-cell marker gene expression, including pluripotency-associated transcription factors such as Oct4, nanog, KLF4, and Sox 2 [4, 5] and adult stem-cell markers such as CD146, CD73, CD90, notch1, and Msi1 [1, 6-8]. Mesenchymal stem-cell properties of endometrial cells were also demonstrated based on multilineage differentiation potential both in vitro and in murine models $[8,9]$. Finally, bonemarrow transplantation experiments between HLA-, or sex-mismatched donors and recipients strongly suggest that bone-marrow-derived stem cells can reconstitute both stroma and glands of the human endometrium $[10,11]$.

\subsection{Stem-Cell Involvement in Endometrial Pathologies}

Based on their specific properties, including unlimited proliferative potential, high expression of multidrugresistance proteins, and high developmental plasticity, it is not surprising that a dysregulation of endometrial stem-cell function may be related to the pathogenesis of proliferative diseases of the endometrium, including endometriosis, endometrial hyperplasia, or endometrial carcinoma [12,13]. For example, our group could recently demonstrate an upregulation of putative endometrial stem-cell numbers expressing the adult stemcell markers Msi1 in endometriosis and endometrial carcinoma [7]. Similarly, expression of the pluripotency factors Sox 2 and Oct4 is dysregulated in endometriosis [4, 14]. siRNA-mediated downregulation of Msi1 in vitro led to a downregulation of notch-signaling pathway components and induced apoptosis in endometrial carcinoma cells, demonstrating the relevance of cancer stem cells for endometrial carcinoma pathogenesis [13]. Further evidence for the presence of cancer stem cells in endometrial carcinoma was provided by the demonstration of a contribution of endometrial side population cells to epithelial-to-mesenchymal transition in endometrial carcinoma [15] and by xenograft studies demonstrating cancer stem-cell activity of clonal endometrial cultures isolated from human endometrial carcinoma biopsies [16].

\subsection{Stem Cell Niche and Hormone Dependency}

Stem cells are hypothesized to reside in a niche, constituting a microenvironment which keeps the stem cell in an undifferentiated state and allows for activation and differentiation of stem and progenitor cells only under controlled conditions when regeneration and proliferation of the tissue is required $[17,18]$. Therefore, pathological alterations of the niche could be part of the mechanism leading to endometriosis or other conditions depending on abnormal endometrial proliferation. The niche is not well characterized yet, but it was hypothesized that it was hormone dependent [19]. This is supported by the fact that endometrium proliferates under estrogen influence and progesterone will cause a secretory state, while progesterone withdrawal will lead to shedding of the endometrium, resulting in menses. In addition, endocrine dysregulation plays a major role in endometrial pathologies, including for example, progesterone resistance in endometriosis [20] or hormone-dependent proliferation of endometrial carcinoma [21, 22]. After injury of the murine endometrium, an increase of side population cells was recently observed, which are probably involved in tissue repair [23]. In this study, in ovariectomized mice, estrogen played a critical role: implantation of estradiol pellets restored the increase of side population cells after endometrial tissue injury by peritoneal injection of lipopolysaccharide. It was concluded that estrogen probably stimulated endometrial regeneration by stimulating stem-cell proliferation [23]. In a different mouse model, endometrial epithelial label retaining cells (LRCs) - a surrogate marker of slow cycling stem cell activity—lacked the expression of estrogen receptor, whereas a small proportion of stromal LRCs expressed estrogen receptor 1 [19]. It was hypothesized that this population of subepithelial stromal LRCs constitutes part of the stem-cell niche, 
conveying estrogen-driven proliferation of epithelial LRCs via paracrine pathways. However, surprisingly, to date, information on the structure of the human endometrial stem-cell niche and its hormone dependency is still scarce. This led us to investigate the expression of $\mathrm{ER} \alpha, \mathrm{ER} \beta$, and progesterone receptor (PR) in clonal stem-cell cultures obtained from human endometrial biopsies, which had previously been shown to display mesenchymal stem-cell properties [8].

\section{MATERIAL AND METHODS}

\subsection{Patients and Endometrial Samples}

Endometrial samples of eleven female patients undergoing pretreatment diagnostics in the reproductive medicine unit of the university hospital were studied. All patients gave written informed consent to this study, which was approved by the local ethics commission (no. 2008-223-f-S) and which was carried out according to the principles of the Helsinki Convention. Transcervical endometrial biopsies were taken on the 22nd to 24th cycle day as part of the diagnostic routine and conducted as published before [8]. Briefly, after cleansing of the vagina with moist sponges a Probet catheter (Gynemed, Lensahn, Germany) was inserted through the nondilated cervical canal. Upon reaching the uterine cavity, the plunger was retracted, and the device was moved forwards and backwards while rotating. Samples were split in two, and one part was analyzed by the pathologist according to established criteria [24], while the remaining part was transferred in HEPES-buffered Dulbecco modified Eagle medium/Hams F-12 (DMEM/F-12, Invitrogen, Carlsbad, Calif, USA).

\subsection{Isolation of Endometrial Stromal Cells}

Isolation of endometrial stromal cells from endometrial biopsies was performed as described before [8]. Briefly, endometrial tissue was enzymatically dissociated by incubation with $300 \mu \mathrm{g} / \mathrm{mL}$ collagenase III (Biochrom, Berlin, Germany) and $40 \mu \mathrm{g} / \mathrm{mL}$ DNAse I (Roche Diagnostics, Mannheim, Germany) for 45$60 \mathrm{~min}$, followed by a 1:10 dilution of the digest in PBS/10\% FCS and a removal of debris and epithelial cell sheets using a $40 \mu \mathrm{m}$ cell strainer (Falcon). Stromal cells were obtained using magnetic Dynabeads (Dynal Biotech, Oslo, Norway) coated with specific antibodies for epithelial cells (BerEP4) and leukocytes (CD45) as essentially described by Chan et al. [25]. Following erythrocyte lysis, the cells were resuspended in DMEM/F-12/10\% FCS medium and seeded on fibronectin-coated 60-mm Petri dishes (Becton Dickinson Biosciences, Bedford, Mass, USA) at a density of 630 cells $/ 3 \mathrm{~mL}$ for serial cloning. Cells were cultured in a humidified incubator at $37^{\circ} \mathrm{C}$ in a $5 \% \mathrm{CO}_{2}$ atmosphere. Clonal density cultures were cultured for 15 days, while the remainder of the cells was cultured for $24 \mathrm{~h}$ after isolation and served as a control.

\subsection{Quantitative Real-Time PCR (qPCR) Analysis}

qPCR was used to analyse the clonal stromal cells for the expression of estrogen receptor alpha (ER $\alpha)$, estrogen receptor beta $(\mathrm{ER} \beta)$, and progesterone receptor (PR). RNA- and cDNA-preparation and qPCR were performed exactly as previously described using the TaqMan gene expression systems hs00174860_m1, hs00230957_m1, and hs001556702_m1 (Applied Biosystems) (see http://www.allgenes.com/ for sequence information). Target gene expression was normalized to 18S rRNA (Hs99999901 s1). Relative quantitation was performed using the comparative cycle threshold method [26]. Statistical analysis was performed using Student's $t$-test. A $P$ value of $<0.05$ was considered statistically significant.

\section{RESULTS}

Eleven endometrial samples were included in the study, a characterization of the respective patients is given in Table 1. All samples were obtained in a secretory phase with a mean serum progesterone concentration 
TABLE 1: Clinical characteristics of patients and change of hormone receptor expression after the first cloning round.

\begin{tabular}{|c|c|c|c|c|c|c|c|c|c|c|c|}
\hline Patient & $\begin{array}{l}\text { Age } \\
\text { (yrs) }\end{array}$ & BMI & $\begin{array}{c}\text { Mis- } \\
\text { carriages }\end{array}$ & Cycle phase & $\begin{array}{l}\text { Histological } \\
\text { cycle day }\end{array}$ & $\begin{array}{l}\text { Progesterone } \\
\text { (ng/mL) }\end{array}$ & $\mathrm{ER} \alpha \mathrm{FC}$ & $\begin{array}{c}\mathrm{ER} \beta \\
\mathrm{FC}\end{array}$ & PR FC & $\begin{array}{c}\mathrm{ER} \beta / \mathrm{ER} \alpha \\
\text { control }\end{array}$ & $\begin{array}{l}\mathrm{ER} \beta / \mathrm{ER} \alpha 1 \text { st } \\
\text { cloning round }\end{array}$ \\
\hline HA & 25 & 21 & 0 & Secretory & 23 & 11.02 & 0.002 & 0.016 & 0.036 & 0.0151 & 0.1199 \\
\hline LK & 36 & 19 & 1 & Secretory & 16 & 13.48 & 0.265 & 0.011 & 0.130 & 0.0090 & 0.0004 \\
\hline LM & 36 & 18 & 0 & Secretory & 23 & 15.00 & 0.281 & 0.008 & 0.607 & 0.1490 & 0.0040 \\
\hline HM & 29 & 25 & 0 & Secretory & 22 & 8.37 & 0.299 & 0.357 & 0.139 & 0.0047 & 0.0057 \\
\hline IV & 24 & 18 & 1 & Secretory & 17 & 18.00 & 0.271 & 0.329 & 0.318 & 0.0082 & 0.0100 \\
\hline YA & 26 & 24 & 0 & Secretory & 22 & 14.61 & 0.002 & 0.009 & 0.035 & 0.0037 & 0.0206 \\
\hline HI & 38 & 23 & 3 & Secretory & 21 & 17.03 & 0.012 & 0.004 & 0.036 & 0.0124 & 0.0044 \\
\hline WS & 29 & 34 & 0 & Secretory & 23 & 9.43 & 0.008 & 0.037 & 0.022 & 0.0059 & 0.0252 \\
\hline $\mathrm{BN}$ & 35 & 29 & 3 & Secretory & 23 & 16.79 & 0.220 & 0.080 & 1.530 & 0.2645 & 0.0959 \\
\hline LF & 42 & 25 & 0 & Secretory & 23 & 12.16 & 1.632 & 0.048 & 5.249 & 0.0054 & 0.0002 \\
\hline $\mathrm{CM}$ & 32 & 23 & 1 & Secretory & 17 & 14.61 & 1.010 & 0.363 & 1.302 & 0.0005 & 0.0002 \\
\hline
\end{tabular}

FC: fold change of hormone receptor expression after the first cloning round.

ER: estrogen receptor; PR: progesterone receptor.

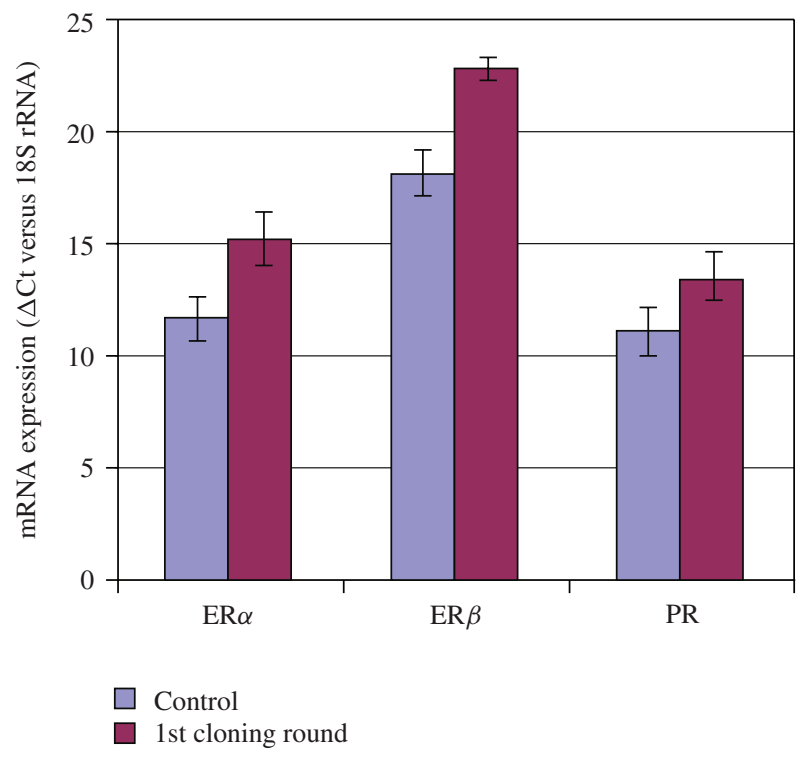

FIGURE 1: $\Delta C t$ values relative to $18 \mathrm{~S}$ rRNA expression of hormone receptor expression in endometrial stroma cell cultures after the first cloning round. Please note that a higher $\Delta C t$ value corresponds to a comparably lower expression level. Error bars $=\mathrm{SEM}, n=11$.

of $13.68(8.37-17.03) \mathrm{ng} / \mathrm{mL}$. Accordingly, endometrial dating corresponded with a mean cycle day of 20.59 (16-23). After obtaining endometrial biopsies, stromal cells were prepared as described previously [8]. One aliquot of the cells was cultured over night at high density to obtain a control cell culture. A second aliquot was plated at clonal density and cultured for 15 days in order to obtain a stem-cell-enriched culture. We have previously shown that expression of stem-cell markers such as CD146 is significantly enriched after serial cloning and that serially passaged long-term cultures have mesenchymal stem-cell-(MSC-) like properties [8]. A qPCR analysis of hormone receptor expression revealed that based on the average $\Delta \mathrm{Ct}$ values of control cell cultures, $\mathrm{ER} \alpha$ and PR were expressed at similar mRNA-levels, whereas $\mathrm{ER} \beta$ expression was about 100-fold lower (Figure 1). Comparing the group as a whole, endometrial MSCs of clonal cultures significantly downregulated expression of $\mathrm{ER} \alpha$ und $\mathrm{ER} \beta$ after the first cloning round $(P<0.01$ and $P<$ 0.001, resp.) (Table 1, Figures 1 and 2). However, down-regulation of PR was not significant for the whole group, caused by up regulation of PR in two patients (BN, LF) and no change of expression in another 


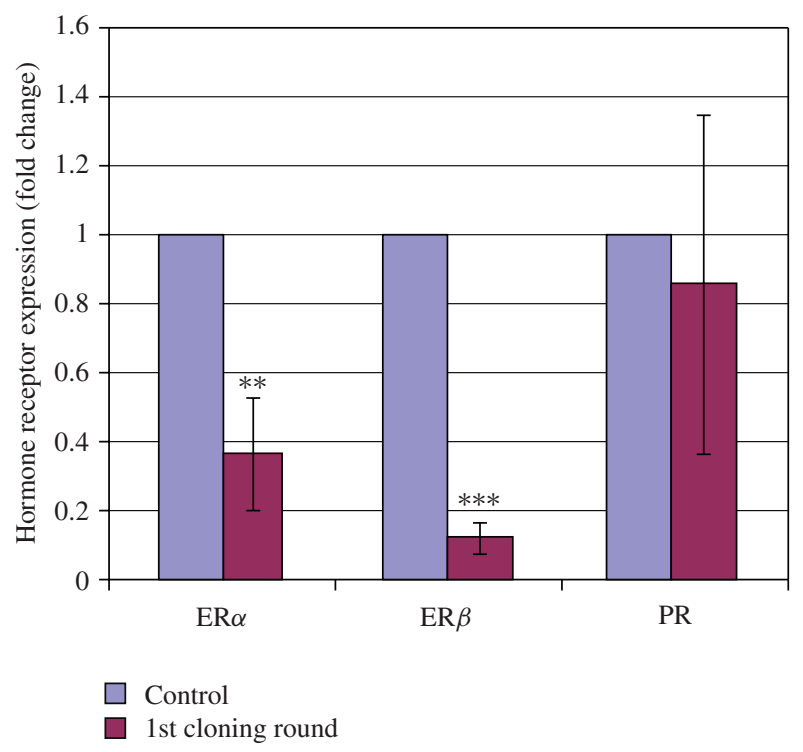

FIGURE 2: Fold change of hormone receptor expression in endometrial stroma cell cultures after the first cloning round. Error bars $=\mathrm{SEM}, n=11, * *=P<0.01, * * *=P<0.001$.

patient (CM). Notably, in two of these patients with differing PCR results for change of PR expression, expression of $\mathrm{ER} \alpha$ was upregulated (LF) or not changed (CM) after the first cloning round. Considering clinical parameters of the three subjects with differing PCR results, a nonsignificant trend towards higher age (36.3 versus 30.4), higher BMI (25.7 versus 22.7), and higher number of miscarriages (1.3 versus 0.6) was found compared with individuals displaying a downregulation of $\operatorname{ER} \alpha, \operatorname{ER} \beta$, and PR after the first cloning round. Information about the presence of endometriosis as assessed by laparoscopy was available in four of the studied individuals: two patients with proof of endometriosis (BN, LK) and two patients with exclusion of endometriosis (LM, LF) were equally distributed between groups. As an imbalance in the ratio of $\mathrm{ER} \beta$ to $\mathrm{ER} \alpha$ expression has been linked to endometrial pathologies such as endometriosis [20], we finally determined possible changes in this ratio linked to an enrichment of stem cells in our clonal stroma cell cultures. The ratio of endometrial $\mathrm{ER} \beta$ to $\mathrm{ER} \alpha$ expression proved to be highly variable between patients (Figure 3, Table 1). Consequently, no significant difference could be determined between control and clonal stem-cell cultures.

\section{DISCUSSION}

In this paper, we report on the expression of $\mathrm{ER} \alpha, \mathrm{ER} \beta$, and $\mathrm{PR}$ in human clonal endometrial stem-cell cultures, finding a significant downregulation of $\operatorname{ER} \alpha$ and $\operatorname{ER} \beta$ after the first cloning round. Notably, expression of PR remained unchanged for the whole group, caused by a varying expression pattern in individual subjects. This study extends the presently limited information available on the putative role of sexual steroids in endometrial stem cells, possibly involved in the unravelled structure and function of the human endometrial stem-cell niche. We and others have previously shown that serial cloning of endometrial stromal cells obtained by minimally invasive transcervical biopsy leads to an enrichment of stem-cell markers and to a multilineage differentiation potential $[8,27]$. Stem cells have been hypothesized to be involved in the cyclic growth and renewal of human endometrium, a tissue of high regenerative capacity [28]. However, while estrogen and progesterone are well-known key endocrine players in the monthly proliferation, differentiation, and shedding of the endometrium, data on stem cells and their role in endocrine regulation of endometrial function is scarce. 


\section{1. $\mathrm{ER} \alpha$}

Our finding of a downregulation of ER $\alpha$ in human endometrial stem cells is in agreement with a report on label retaining cells (LRCs) of the mouse endometrium, which downregulate ER $\alpha$, supporting the concept of stem cells as nondifferentiated entities lacking specific differentiation markers [19]. Supporting these findings, the first report on endocrine properties of endometrial stem cells in humans recently observed that cellular suspensions of human endometrial side population cell lines lacked expression of ER $\alpha$ in either epithelial stem-cell line (ICEp) or stromal stem-cell line (ICEs) [27].

\section{2. $P R$}

However, while in the latter studies expression of PR was also downregulated, the expression of PR in our collective was unchanged after the first cloning round. Notably, the lack of change in PR expression for the whole group was caused by a distinct variability of PR expression, displaying an upregulation or no change of expression in individual subjects. We can only speculate about this rather unexpected finding in some of our clonal cell colonies. In a mouse model, a portion of stromal endometrial stem cells were capable of expressing $\mathrm{ER} \alpha$, and it was speculated that these hormone responsive cells represent a part of the stem-cell niche controlling proliferation of epithelial stem cells via paracrine pathways [19]. However, an increased expression of PR in endometrial stem cells has not been reported to date [19,27]. Because our endometrial samples were obtained under standardized conditions in a luteal phase as confirmed by progesterone serum concentrations and histological endometrial dating, the observed upregulation of PR in some of our patients could support the hypothesis that our time point of sample acquisition has enriched these cells expressing PR and that they reflect a phenotypic trait of the stem-cell niche presenting in secretory endometrium. From the only other study to date investigating $\mathrm{ER} \alpha$ and PR in human endometrial stem cells, no information is available about the cycle phase in which endometrial biopsies were obtained [27]. While we can only speculate about the relevance of our findings, evaluation of clinical parameters in patients with a differing expression pattern of PR revealed a trend for conditions associated with endometrial malfunction such as a higher age, a higher BMI, and an increased prevalence of miscarriages. It is, therefore, possible that our collective included patients with an impaired endometrial function which led to an activation of the stemcell niche as proposed before [28]. Application of minimally invasive endometrial biopsies will allow for the evaluation of a larger sample size in well-characterized subjects and help to clarify the role of stem cells in endometrial pathology [8].

\section{3. $\operatorname{ER} \beta$}

For the first time, we report on the change of $\operatorname{ER} \beta$ mRNA-expression in human endometrial stem cells of clonal cultures. Physiologically, $\mathrm{ER} \beta$ is considered to exert a modulating impact on ER $\alpha$-mediated endometrial responses, possibly promoting glandular differentiation [29]. Additionally, a possible pathological role for $\operatorname{ER} \beta$ in the etiology of endometriosis has recently emerged. In endometriotic tissue, an elevated $\operatorname{ER} \beta$ to $\mathrm{ER} \alpha$ ratio was hypothesized to decrease PR expression, which could contribute to progesterone resistance, a suspected causal factor for the development of endometriosis [20]. However, when ER $\beta$ to ER $\alpha$ ratio was determined in our endometrial stem-cell cultures, no significant difference could be observed in comparison to controls.

\section{CONCLUSION}

In conclusion, our results are further proof for the presence of stem cells in human endometrium which can be obtained by minimally invasive transcervical biopsies, allowing for large-scale studies. The here-reported findings in clonal cultures support the concept of human endometrial stem cells downregulating expression of $\operatorname{ER} \alpha$ and $\operatorname{ER} \beta$. The novel finding of a varying PR expression in clonal cultures could help to characterize 


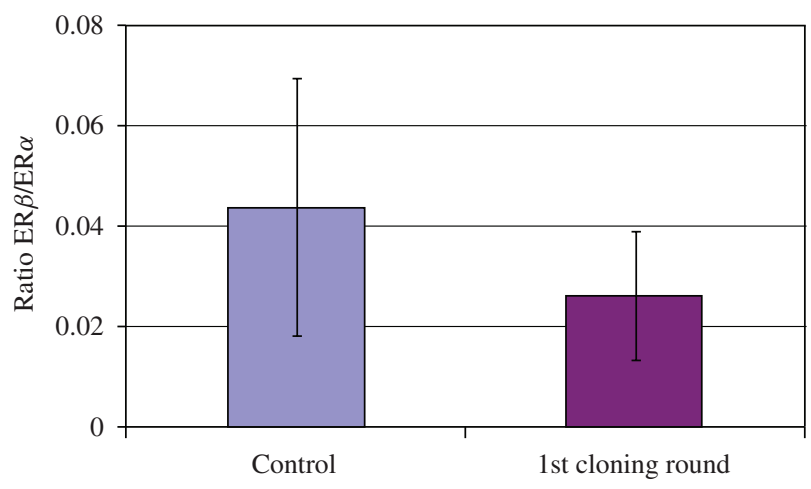

FIGURE 3: Ratio of $\mathrm{ER} \beta$ - to $\mathrm{ER} \alpha$-expression in endometrial stroma cell cultures after the first cloning round. Error bars $=$ SEM, $n=11, P=n . s$.

part of the unravelled stem-cell niche, which appears to convey the endocrine signal of sexual steroids to stem cells by paracrine signal ways. Our observations also suggest that clinical information about individual subjects may be of interest in future studies, promoting the evaluation of well-characterized populations including endocrine and reproductive data associated with endometrial capacity.

\section{ACKNOWLEDGMENTS}

The authors would like to thank Birgit Pers and Barbara Kloke for expert technical assistance.

\section{REFERENCES}

[1] C. E. Gargett, K. E. Schwab, R. M. Zillwood, H. P. T. Nguyen, and D. Wu, "Isolation and culture of epithelial progenitors and mesenchymal stem cells from human endometrium," Biology of Reproduction, vol. 80, no. 6, pp. 1136-1145, 2009.

[2] M. Tanaka, S. Kyo, T. Kanaya et al., "Evidence of the monoclonal composition of human endometrial epithelial glands and mosaic pattern of clonal distribution in luminal epithelium," American Journal of Pathology, vol. 163, no. 1, pp. 295-301, 2003.

[3] J. Y. Kim, S. Tavaré, and D. Shibata, "Counting human somatic cell replications: methylation mirrors endometrial stem cell divisions," Proceedings of the National Academy of Sciences of the United States of America, vol. 102, no. 49, pp. 17739-17744, 2005.

[4] M. Götte, M. Wolf, A. Staebler, O. Buchweitz, L. Kiesel, and A. N. Schüring, "Aberrant expression of the pluripotency marker SOX-2 in endometriosis," Fertility and Sterility, vol. 95, no. 1, pp. 338-341, 2011.

[5] J. H. Park, L. Daheron, S. Kantarci, B. S. Lee, and J. M. Teixeira, "Human endometrial cells express elevated levels of pluripotent factors and are more amenable to reprogramming into induced pluripotent stem cells," Endocrinology, vol. 152, pp. 1080-1089, 2011.

[6] K. E. Schwab, P. Hutchinson, and C. E. Gargett, "Identification of surface markers for prospective isolation of human endometrial stromal colony-forming cells," Human Reproduction, vol. 23, no. 4, pp. 934-943, 2008.

[7] M. Götte, M. Wolf, A. Staebler et al., "Increased expression of the adult stem cell marker Musashi-1 in endometriosis and endometrial carcinoma," Journal of Pathology, vol. 215, no. 3, pp. 317-329, 2008.

[8] A. N. Schüring, N. Schulte, R. Kelsch, A. Röpke, L. Kiesel, and M. Götte, "Characterization of endometrial mesenchymal stem-like cells obtained by endometrial biopsy during routine diagnostics," Fertility and Sterility, vol. 95, no. 1, pp. 423-426, 2011.

[9] I. Cervelló, C. Gil-Sanchis, A. Mas et al., "Human endometrial side population cells exhibit genotypic, phenotypic and functional features of somatic stem cells," PLoS ONE, vol. 5, no. 6, Article ID e10964, 2010.

[10] H. S. Taylor, "Endometrial cells derived from donor stem cells in bone marrow transplant recipients," Journal of the American Medical Association, vol. 292, no. 1, pp. 81-85, 2004. 
[11] T. Ikoma, S. Kyo, Y. Maida et al., "Bone marrow-derived cells from male donors can compose endometrial glands in female transplant recipients," American Journal of Obstetrics and Gynecology, vol. 201, no. 6, pp. e1-e8, 2009.

[12] C. E. Gargett and R. W. S. Chan, "Endometrial stem/progenitor cells and proliferative disorders of the endometrium," Minerva Ginecologica, vol. 58, no. 6, pp. 511-526, 2006.

[13] M. Götte, B. Greve, R. Kelsch et al., "The adult stem cell marker musashi-1 modulates endometrial carcinoma cell cycle progression and apoptosis via notch-1 and p21(WAF1/CIP1)," International Journal of Cancer, vol. 129, pp. 2042-2049, 2011.

[14] A. Pacchiarotti, D. Caserta, M. Sbracia, and M. Moscarini, "Expression of oct-4 and c-kit antigens in endometriosis," Fertility and Sterility, vol. 95, pp. 1171-1173, 2011.

[15] K. Kato, T. Takao, A. Kuboyama et al., "Endometrial cancer side-population cells show prominent migration and have a potential to differentiate into the mesenchymal cell lineage," American Journal of Pathology, vol. 176, no. 1, pp. 381-392, 2010.

[16] S. A. Hubbard, A. M. Friel, B. Kumar, L. Zhang, B. R. Rueda, and C. E. Gargett, "Evidence for cancer stem cells in human endometrial carcinoma," Cancer Research, vol. 69, no. 21, pp. 8241-8248, 2009.

[17] I. Cervelló and C. Simón, "Somatic stem cells in the endometrium," Reproductive Sciences, vol. 16, no. 2, pp. 200-205, 2009.

[18] P. G.M. Figueira, M. S. Abrão, G. Krikun, and H. Taylor, "Stem cells in endometrium and their role in the pathogenesis of endometriosis," Annals of the New York Academy of Sciences, vol. 1221, no. 1, pp. 10-17, 2011.

[19] R. W. S. Chan and C. E. Gargett, "Identification of label-retaining cells in mouse endometrium," Stem Cells, vol. 24, no. 6, pp. 1529-1538, 2006.

[20] S. E. Bulun, Y. H. Cheng, M. E. Pavone et al., "Estrogen receptor- $\alpha$, Estrogen receptor- $\beta$, and progesterone resistance in endometriosis," Seminars in Reproductive Medicine, vol. 28, no. 1, pp. 36-43, 2010.

[21] C. Gründker, A. R. Günthert, and G. Emons, "Hormonal heterogeneity of endometrial cancer," Advances in Experimental Medicine and Biology, vol. 630, pp. 166-188, 2008.

[22] M. Götte, "Endometrial cells get side-tracked: side population cells promote epithelial-mesenchymal transition in endometrial carcinoma," American Journal of Pathology, vol. 176, no. 1, pp. 25-28, 2010.

[23] S. Hyodo, K. Matsubara, K. Kameda, and Y. Matsubara, "Endometrial injury increases side population cells in the uterine endometrium: a decisive role of estrogen," The Tohoku Journal of Experimental Medicine, vol. 224, no. 1, pp. 47-55, 2011.

[24] R. W. Noyes, A. T. Hertig, and J. Rock, "Dating the endometrial biopsy," Fertility and Sterility, vol. 1, pp. 3-25, 1950.

[25] R. W. S. Chan, K. E. Schwab, and C. E. Gargett, "Clonogenicity of human endometrial epithelial and stromal cells," Biology of Reproduction, vol. 70, no. 6, pp. 1738-1750, 2004.

[26] K. J. Livak and T. D. Schmittgen, "Analysis of relative gene expression data using real-time quantitative PCR and the 2(-Delta Delta C(T)) Method," Methods, vol. 25, no. 4, pp. 402-408, 2001.

[27] I. Cervelló, A. Mas, C. Gil-Sanchis et al., "Reconstruction of endometrium from human endometrial side population cell lines," PLoS ONE, vol. 6, no. 6, Article ID e21221, 2011.

[28] C. E. Gargett, "Uterine stem cells: what is the evidence?" Human Reproduction Update, vol. 13, no. 1, pp. 87$101,2007$.

[29] O. Wada-Hiraike, H. Hiraike, H. Okinaga et al., "Role of estrogen receptor $\alpha$ in uterine stroma and epithelium: insights from estrogen receptor $\alpha$-/- mice," Proceedings of the National Academy of Sciences of the United States of America, vol. 103, no. 48, pp. 18350-18355, 2006.

\section{This article should be cited as follows:}

A. N. Schüring, J. Braun, S. Wüllner, L. Kiesel, and M. Götte, "mRNA-Expression of ER $\alpha$, ER $\beta$, and PR in Clonal Stem Cell Cultures Obtained from Human Endometrial Biopsies," TheScientificWorldJOURNAL, vol. 11, pp. 1762-1769, 2011. 


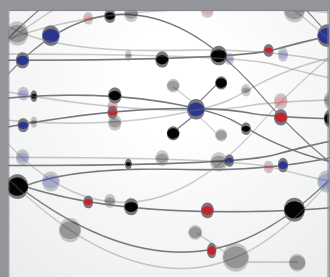

The Scientific World Journal
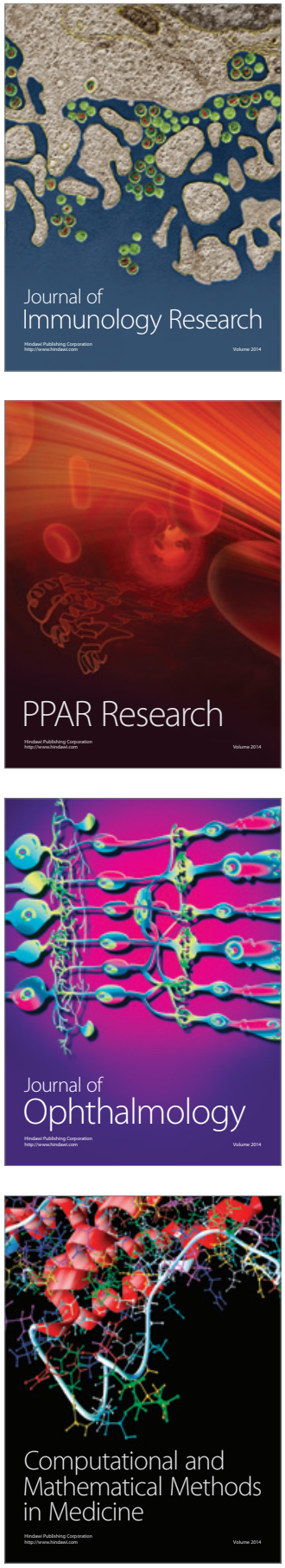

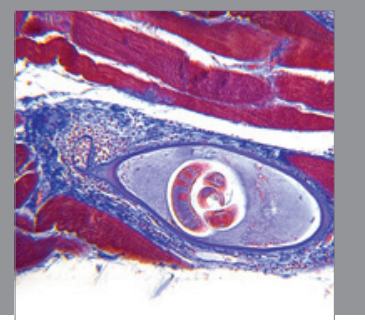

Gastroenterology

Research and Practice
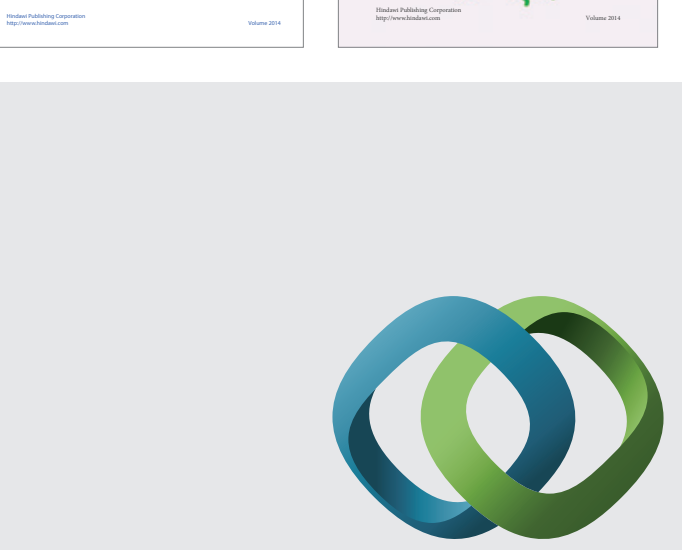

\section{Hindawi}

Submit your manuscripts at

http://www.hindawi.com
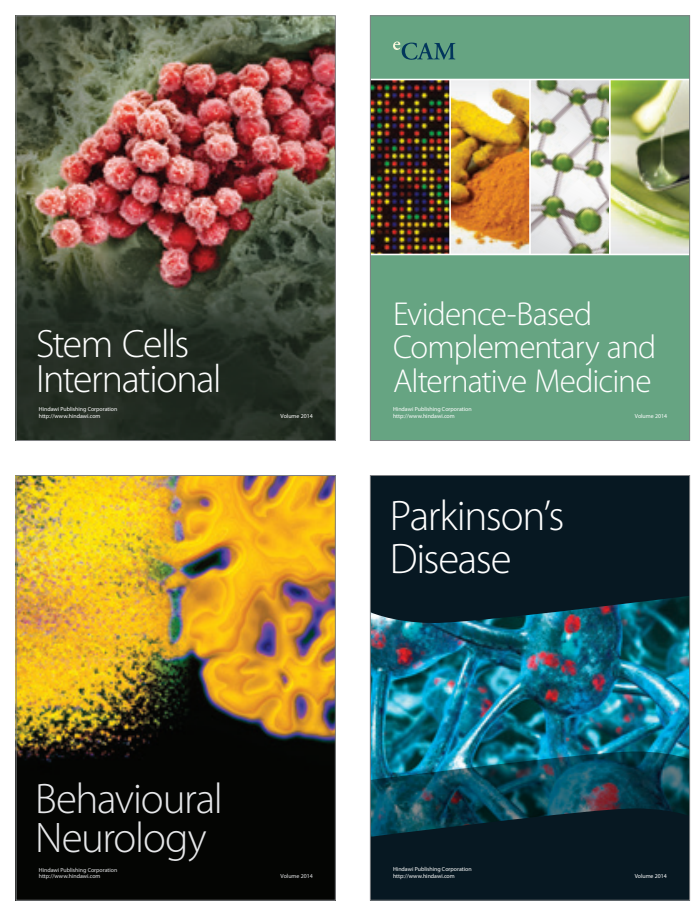

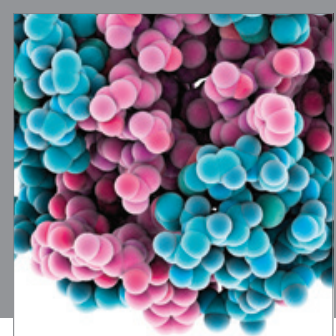

Journal of
Diabetes Research

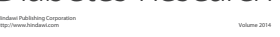

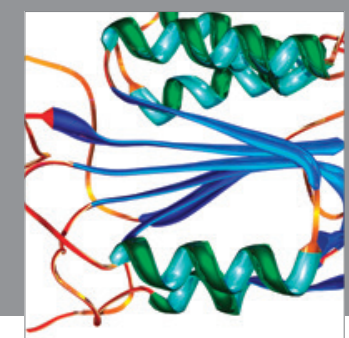

Disease Markers
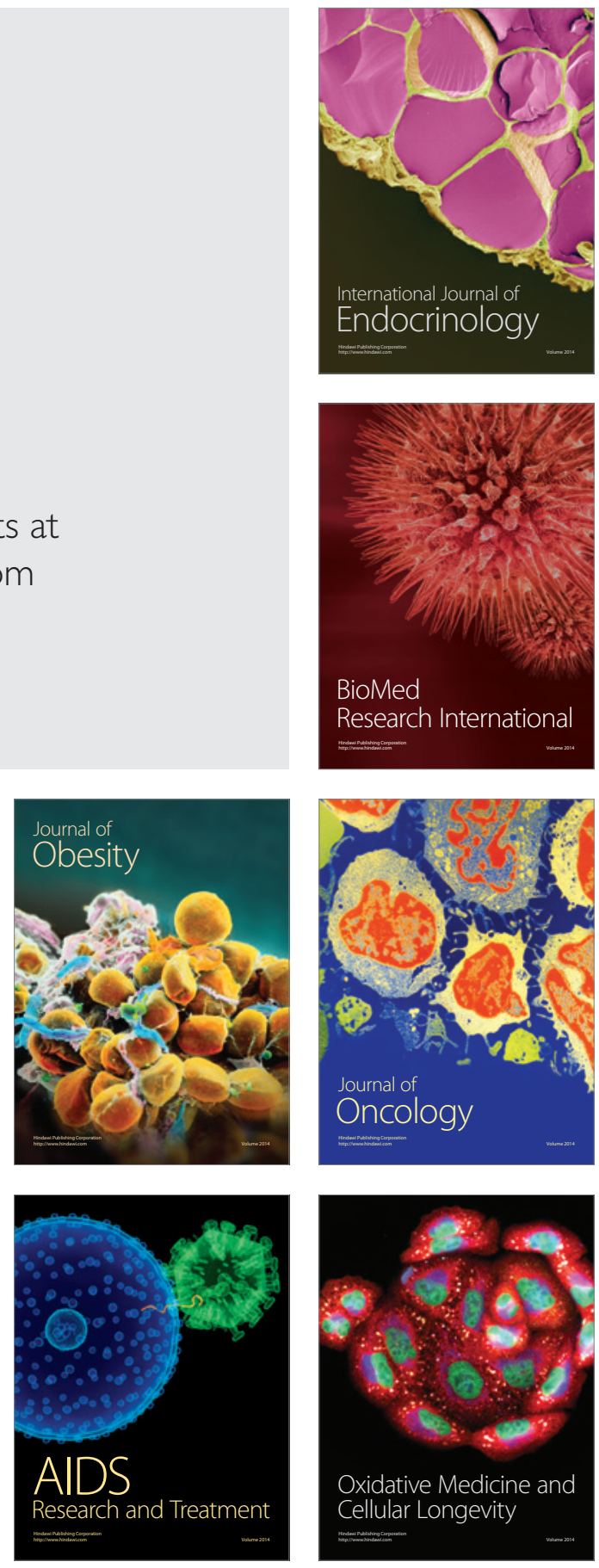